\title{
Laparoscopic splenectomy in an elderly patient with splenic limphoma and splenomegaly
}

\author{
G Antonelli $i^{*}$, R Gianesini ${ }^{1}$, E Mion ${ }^{1}$, C Terranova $^{2}$, L De Santis $^{1}$ \\ From de Senectute: Age and Health Forum \\ Catanzaro, Italy. 5-7 December 2009
}

\section{Background}

Limphomas represent a group of complex neoplastic diseases, characterized by hyperplasia and colonization of neoplastic lymphoid cells (T or B).

The aim of this study was to evaluate the result of laparoscopic surgery for the treatment of a splenic limphoma with splenomegaly in an elderly patient.

\section{Materials and methods}

Patient of 69 years, lipothymia and anemia, Hb 11,2 gr/ $\mathrm{dl}$, leukocytis $7780 / \mathrm{dl}$ (neutrophilis 21,4\%, lymphocytis 68,9\%) PLTs 81000/dl, VES $34 \mathrm{~mm} / \mathrm{h}$ (n.v. 2 -28).

Abdomen ultrasonography: spleen increased in volume (bipolar diameter 21,8 cm), bright liver. TC abdomen: spleen increased of volume, with inferior pole in Douglas.

Medullar biopsy: NH limphoma B-cell.

Patient was candidate to undergo to laparoscopic splenectomy.

Laparoscopy with open technique. Section of gastric breves vessels, closure of splenic artery. Section of freno-colic and freno-lienal ligaments, section of parietal peritoneum near the spleen.

Section of splenic vessels on the inferior pole and section of the grande omento. Section of splenic vein with vascular EndoGia. Legature with titanium clips and section of splenic artery. Lymph-nodes of splenic ilo are removed en-bloc with the spleen. Liver biopsy. Ombelicus-pubic laparotomy to take the specimen.

\section{Results}

There were no intra- and post-operative complications and the patient resumed oral food intake on the $8^{\text {th }}$ day. The definitive histological exam showed: spleen of abnormal size (diameters cm. 30x24×9, weight gr 2063),

'Department of Surgery, Hospital "San Lorenzo", Valdagno - VI, Italy
12 lymph-nodes. NH B-cell limphoma, mantle cell (liver, splenic, lymphonodal localization). (Figure 1)

\section{Conclusions}

Laparoscopic surgery in elderly patients reduces postoperative pain, length of ileum and cardiopulmonary

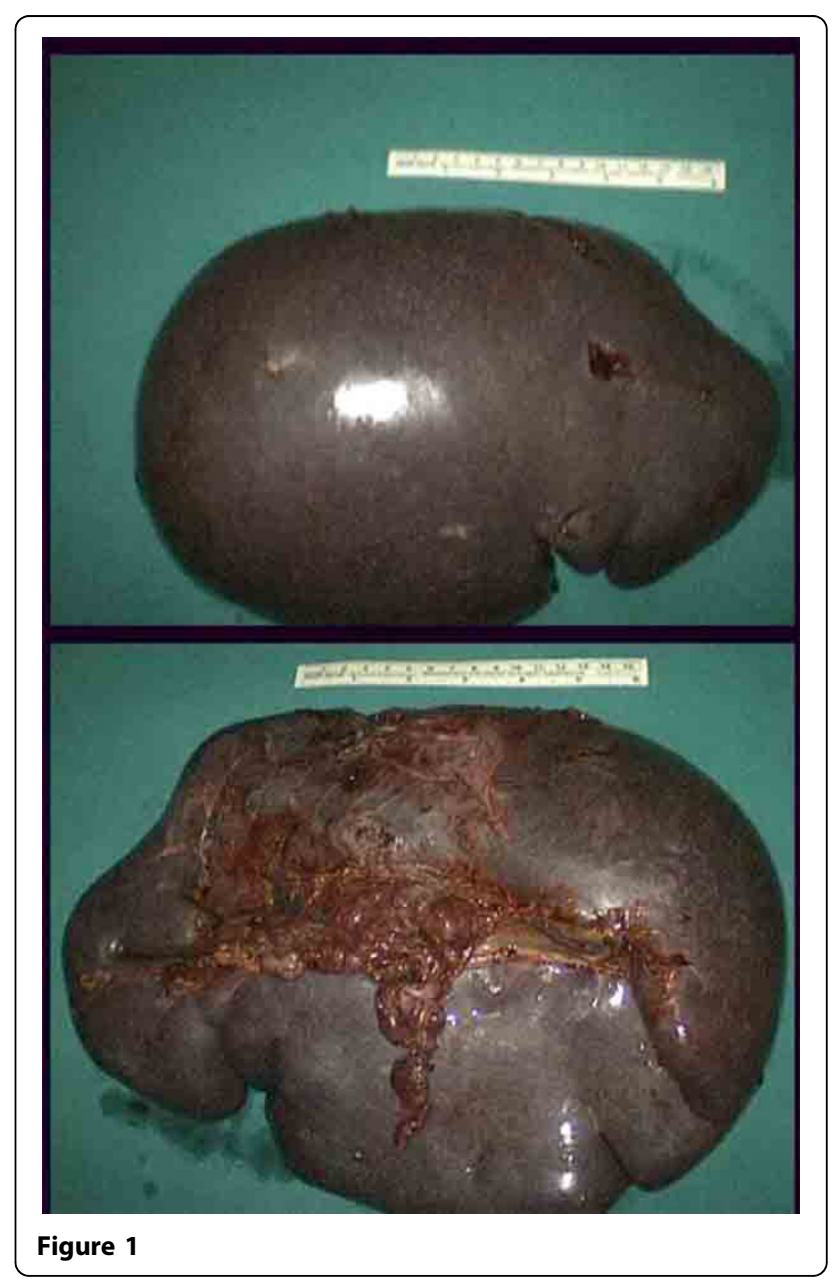


post-operative deficit [1-3]. In laparoscopic surgery the post-operative immune response is less reduced compared to open surgery, because of minor surgical stress and because fewer blood transfusions are required, above all in patients with lymphoma who have to undergo to a splenectomy with a higher risk of postoperative infections (Neisseria Meningiditis, Streptococcus Pneumoniae) [2-4].

In haematological disease, lapaparoscopic surgery is also very useful in order to have a diagnosis, with less post-operative complication than open surgery and, predominantly in very big size spleens, reduce the probability of spleen trauma during operation $[3,4]$.

\section{Author details}

'Department of Surgery, Hospital "San Lorenzo", Valdagno - VI, Italy .

Department of Legal Medicin, Padova University, Italy.

Published: 19 May 2010

\section{References}

1. Walsh RM, Brody F, Brown N: Laparoscopic splenectomy for lymphoproliferative disease. Surg Endosc. 2004, 18(2):272-5, Epub 2003 Dec 29.

2. Rosen M, Brody F, Walsh RM, Tarnoff M, Malm J, Ponsky J: Outcome of laparoscopic splenectomy based on hematologic indication. Surg Endosc 2002, 16(2):272-9, Epub 2001 Nov 12.

3. Monteferrante E, Giunta A, Bigi L, Colecchia G, Della Valle E, Bonacini S, Pedrazzoli C, Ciarelli F, Colangelo E, Liberatore E, Nardi M, Basti M, Prati R: Splenectomy for hematologic disease. Mini-invasive versus traditional technique. Minerva Chir. 2001, 56(3):229-35.

4. Carlini M, Giovannini C, Castaldi F, Cianciulli P, Sorrentino F, Mercadante E: Laparoscopic splenectomy in haematological diseases: short- and medium-term results in thirty initial cases. Chir Ital. 2009, 61(4):427-33.

doi:10.1186/1471-2318-10-S1-A2

Cite this article as: Antonelli et al:: Laparoscopic splenectomy in an elderly patient with splenic limphoma and splenomegaly. BMC Geriatrics 2010 10(Suppl 1):A2.

\section{Submit your next manuscript to BioMed Central} and take full advantage of:

- Convenient online submission

- Thorough peer review

- No space constraints or color figure charges

- Immediate publication on acceptance

- Inclusion in PubMed, CAS, Scopus and Google Scholar

- Research which is freely available for redistribution

Submit your manuscript at www.biomedcentral.com/submit
C Biomed Central 